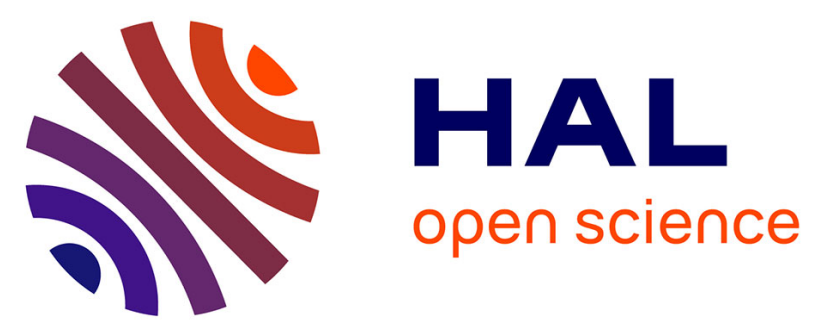

\title{
Maintenance of Low-Pressure Carburising Furnaces: A Source of PAH Exposure
}

Catherine Champmartin, Fanny Jeandel, Hubert Monnier

\section{To cite this version:}

Catherine Champmartin, Fanny Jeandel, Hubert Monnier. Maintenance of Low-Pressure Carburising Furnaces: A Source of PAH Exposure. Annals of Work Exposures and Health, 2017, 61 (3), pp.321332. 10.1093/annweh/wxw024 . hal-01501941

\section{HAL Id: hal-01501941 https://hal.science/hal-01501941}

Submitted on 4 Apr 2017

HAL is a multi-disciplinary open access archive for the deposit and dissemination of scientific research documents, whether they are published or not. The documents may come from teaching and research institutions in France or abroad, or from public or private research centers.
L'archive ouverte pluridisciplinaire HAL, est destinée au dépôt et à la diffusion de documents scientifiques de niveau recherche, publiés ou non, émanant des établissements d'enseignement et de recherche français ou étrangers, des laboratoires publics ou privés. 


\title{
Maintenance of low-pressure carburising furnaces: a source of PAH exposure
} Catherine CHAMPMARTIN ${ }^{1, *}$, Fanny JEANDEL ${ }^{1}$, Hubert MONNIER ${ }^{1}$

${ }^{1}$ Institut National de Recherche et de Sécurité, INRS 1, rue du Morvan, Vandœuvre-lès-Nancy 54519, France

*Author to whom correspondence should be addressed. Tel: +33-3-83-50-85-34; e-mail: catherine.champmartin@inrs.fr

\begin{abstract}
Objectives: Low-pressure carburising is a new technology used to harden steel; the process has been shown to be a source of considerable PAH (Polycyclic Aromatic Hydrocarbons) pollution. Some PAH are carcinogenic, and activities such as furnace maintenance may thus represent a risk to workers. Occupational exposure during these operations should therefore be assessed.
\end{abstract}

Methods: In this study, the PAH-related carcinogenic risk associated with furnace maintenance was assessed by monitoring atmospheric levels of benzo[a]pyrene (BaP), a representative marker, alongside urinary levels of 3-hydroxybenzo[a]pyrene (3-OHBaP), one of its metabolites. PAH exposure levels were monitored during seven sampling campaigns in four different factories specialised in heat-treatment of mechanical workpieces for the automotive and helicopter industries. Two types of furnace were studied, and 37 individuals were monitored.

Results: Values up to 20-fold the French regulatory value of $150 \mathrm{ng} / \mathrm{m}^{3}$ for atmospheric BaP, and, for urinary 3-OHBaP values up to 40-fold the French Biological Limit Value (BLV) of $0.35 \mathrm{nmol} / \mathrm{mol}$ of creatinine were detected. Very high concentrations of $\mathrm{BaP}$, close to or even exceeding those found in coal-tar pitch (up to about $20 \mathrm{~g} / \mathrm{kg}$ ), were measured in residues (tars, dusts) deposited inside the furnace. Even when adequate and suitable personal protective equipment was used, urinary 3-OHBaP values often exceeded the BLV. We hypothesise that this exposure is linked to insidious and fortuitous dermal contamination through contact with factory equipment and staining.

Keywords: vacuum case hardening, occupational exposure, Polycyclic Aromatic Hydrocarbons, benzo[a]pyrene, 3-hydroxybenzo[a]pyrene, dermal exposure 


\section{INTRODUCTION}

Low-pressure carburising is performed in a vacuum furnace using hydrocarbon gases at pressures below $2000 \mathrm{~Pa}$ and high temperatures. Pyrolysis of these gases causes atomic carbon to form and diffuse within the steel to reach a superficial content ranging from 0.7 to 0.9\% wt (Coppin et al., 2000; Dulcy and Gantois 2007). In addition to carburised steel, this process produces by-products, including Polycyclic Aromatic Hydrocarbons (PAH) which contain carcinogenic substances such as benzo[a]pyrene (BaP) (IARC, 2012). These byproducts condense as soot or tar in cold zones within the furnace (dead zones and exhaust pipes), and some fine particles can become dissolved in the oil of the vacuum pumps.

Workers can be exposed to these substances by inhalation and skin contact when the furnace is opened during maintenance and cleaning operations. These operations are generally conducted monthly (light maintenance) or yearly when production is stopped.

To prevent carcinogenic effects in workers exposed to PAH, since the 1970s the French National Health Insurance Fund has recommended a limit value of $150 \mathrm{ng} / \mathrm{m}^{3}$ for $\mathrm{BaP}$ in inhaled air (CNAMTS, 1984). However, air monitoring only reflects potential inhalation exposure. PAH exposure can also be assessed by urinary biomonitoring and compared with air monitoring to consider all exposure routes, including dermal absorption which is potentially a significant route of exposure for PAH (Van Rooij et al., 1993, 1994, McClean et al., 2004). Biomonitoring also has the advantage of assessing the actual exposure levels when personal protective equipment is worn. Although 1-hydroxypyrene has been used for more than 25 years as a biomarker, its relevance as an indirect marker for carcinogenic PAH has been the subject of debate (Gündel et al., 2000; Gendre et al., 2002; Förster et al., 2008; Barbeau et al., 2015). This debate has intensified since selective and sufficiently sensitive methods were developed to quantify 3-hydroxybenzo[a]pyrene (3-OHBaP), a metabolite of BaP (Simon et al., 2000; Barbeau et al., 2011). 3-OHBaP was used as a biomarker in a number of recent studies (Lutier et al., 2016; Barbeau et al., 2014, 2015; Scheepers et al., 2009; Förster et al., 2008), and the French Research and Safety Institute for the Prevention of Occupational Accidents and Diseases (INRS) has proposed a Biological Limit Value (BLV) for French workers of $0.35 \mathrm{nmol} / \mathrm{mol}$ creatinine or $0.83 \mathrm{ng} / \mathrm{g}$ creatinine (Lafontaine et al., 2004 updated by Lafontaine, 2008), for samples taken at the beginning of the shift following exposure.

This article assesses exposure to $\mathrm{BaP}$ in furnace maintenance workers by measuring airborne $\mathrm{BaP}$ concentrations and $3-\mathrm{OHBaP}$ in urine. The aim was to determine whether exposure to 
$\mathrm{BaP}$ occurs, and to provide a comprehensive overall picture of exposure in this sector. To help with the development of risk management strategies, the main routes of exposure (dermal / respiratory) are also discussed.

\section{MATERIAL AND METHODS}

\subsection{Furnace description}

Two kinds of linked multi-chamber vacuum furnaces were studied. Both furnaces have one or more heating chambers and one or two quenching chambers. All the chambers are linked together by a rail-mounted transport cart. In the Central Tunnel Loading Furnace (CTLF), cylindrical chambers are placed around a central tunnel and the entire system is maintained under vacuum (Figure 1a). The steel workpieces, laid on a transfer cart, are moved from the charging chamber to a heating chamber for carburising and then to the quenching chamber, passing through the tunnel each time. In the Front Loading Furnace (FLF), the chambers are placed in a line along a track, and each heating chamber can be independently maintained under vacuum (Figure 1b). A shuttle module moves and stands flush against the chamber for loading or unloading. The carburising gas can be either propane or acetylene (Table 1). 

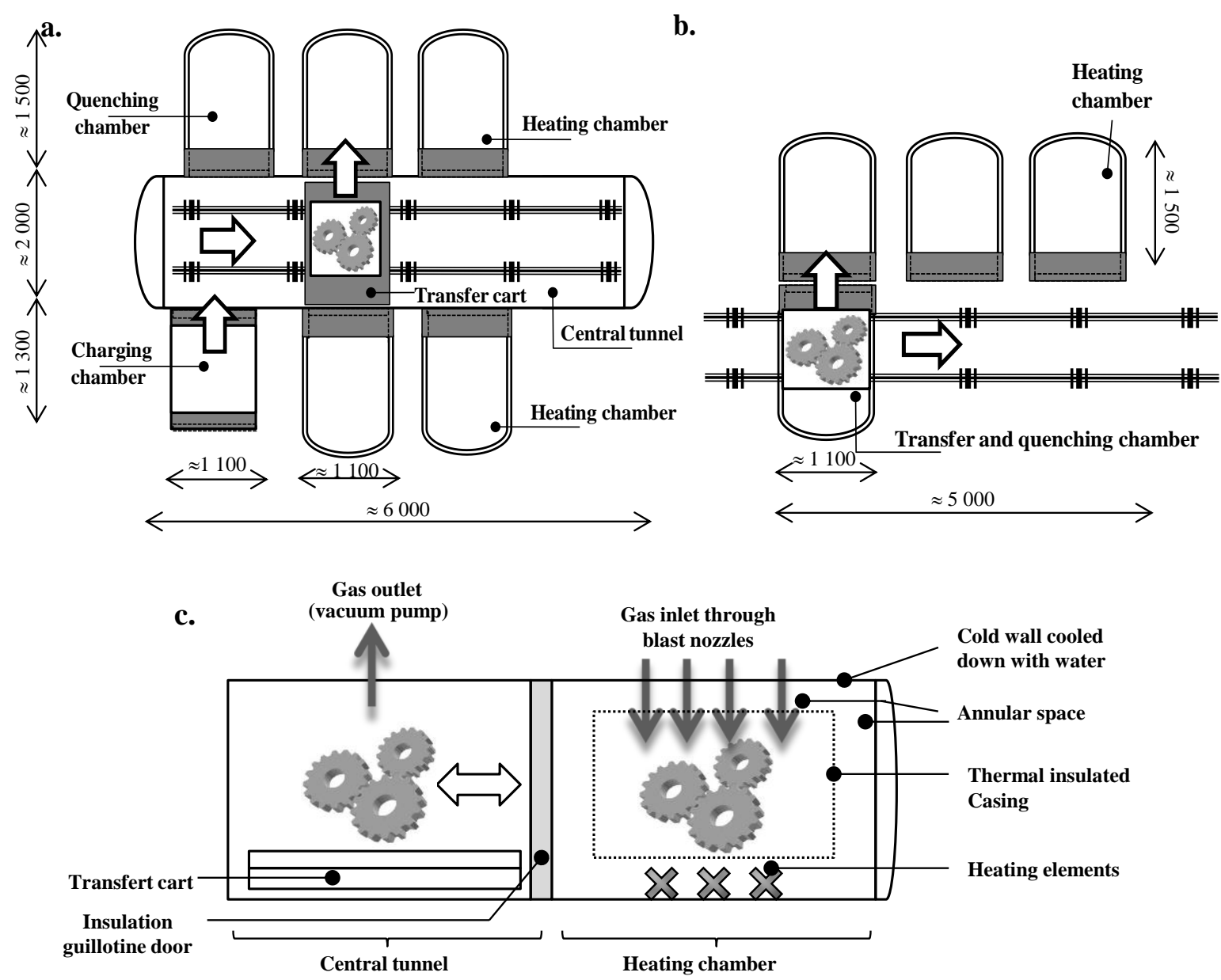

Figure 1: Schematic views of vacuum furnaces: a four-chamber Central Tunnel Loading Furnace (CTLF) (a), a three-chamber Front Loading Furnace (FLF) (b), a partial sectional view of a CTLF $(c)$ - diagrams are not to scale. White arrows indicate the path followed by the steel workpieces during production. All dimensions are in millimetres.

\subsection{Study population}

The measurement campaigns took place in four factories specialised in the heat-treatment of mechanical workpieces for the automotive and helicopter manufacturing industries. The volunteer subjects were 37 healthy males allocated to maintenance and cleaning operations on the furnaces. Monitoring was performed during seven interventions, combining simultaneous sampling of airborne $\mathrm{BaP}$ and urinary 3-OHBaP (Table 1). A questionnaire was used to gather information on the volunteers' smoking habits. The population was composed of 15 smokers and 22 non-smokers. 
Table 1. Summary and description of the monitoring campaigns - 37 subjects

\begin{tabular}{|c|c|c|c|c|c|c|c|c|c|c|c|c|c|}
\hline \multicolumn{2}{|l|}{ Factories } & \multicolumn{2}{|c|}{ Factory 1} & \multicolumn{3}{|c|}{ Factory 2} & \multicolumn{4}{|c|}{ Factory 3} & \multicolumn{3}{|c|}{ Factory 4} \\
\hline \multicolumn{2}{|c|}{ Type of furnace } & \multicolumn{2}{|c|}{ CTLF $^{\mathrm{a}}$} & \multicolumn{3}{|c|}{ FLF $^{b}$} & \multicolumn{4}{|c|}{ CTLF } & \multicolumn{3}{|c|}{ CTLF } \\
\hline \multicolumn{2}{|c|}{ Carburising gas } & \multicolumn{2}{|c|}{ propane } & \multicolumn{3}{|c|}{ acetylene } & \multicolumn{4}{|c|}{ propane } & \multicolumn{3}{|c|}{ acetylene } \\
\hline \multicolumn{2}{|c|}{$\begin{array}{l}\text { Year of exposure } \\
\text { assessment }\end{array}$} & 2008 & 2009 & 2008 & \multicolumn{2}{|c|}{2009} & \multicolumn{2}{|c|}{2010} & \multicolumn{2}{|c|}{2011} & \multicolumn{3}{|c|}{2012} \\
\hline \multicolumn{2}{|c|}{$\begin{array}{l}\text { Number of workers } \\
\text { monitored }\end{array}$} & 6 & 4 & 2 & & 2 & 8 & & 8 & & & 7 & \\
\hline \multirow{3}{*}{$\begin{array}{c}\text { Respiratory } \\
\text { Protection } \\
\text { Equipment } \\
\text { (RPE) }\end{array}$} & description & none used & $\begin{array}{c}\text { Filtering } \\
\text { Facepiece } \\
\text { Respirators }\end{array}$ & none used & $\begin{array}{l}\text { Full } \\
\text { Face } \\
\text { Mask }\end{array}$ & $\begin{array}{c}\text { Powered } \\
\text { Hood }\end{array}$ & $\begin{array}{c}\text { Reusable } \\
\text { Half } \\
\text { Mask }\end{array}$ & $\begin{array}{c}\text { Full } \\
\text { Face } \\
\text { Mask }\end{array}$ & $\begin{array}{c}\text { Filtering } \\
\text { Facepiece } \\
\text { Respirators }\end{array}$ & \begin{tabular}{|c|} 
Full \\
Face \\
Mask \\
(for \\
one \\
worker)
\end{tabular} & $\begin{array}{c}\text { Filtering } \\
\text { Facepiece } \\
\text { Respirators }\end{array}$ & $\begin{array}{c}\text { Reusable } \\
\text { Half } \\
\text { Mask }\end{array}$ & $\begin{array}{c}\text { Reusable } \\
\text { Half } \\
\text { Mask }\end{array}$ \\
\hline & Class & \multirow[b]{2}{*}{-} & P3 & \multirow[b]{2}{*}{-} & P3 & P3 & P3 & P3 & $\mathrm{P} 2$ & $\mathrm{P} 3$ & P3 & $\mathrm{P} 2$ & P3 \\
\hline & \begin{tabular}{|c|} 
Assigned \\
Protection \\
Factor in \\
UK \\
(AFNOR, \\
2006) \\
\end{tabular} & & 20 & & 40 & 40 & 20 & 40 & 10 & 40 & 20 & 10 & 20 \\
\hline \multirow{2}{*}{$\begin{array}{l}\text { Skin } \\
\text { protection }\end{array}$} & Suit & - & $\begin{array}{l}\text { disposable } \\
\text { protective }\end{array}$ & - & \multicolumn{2}{|c|}{$\begin{array}{l}\text { disposable } \\
\text { protective }\end{array}$} & \multicolumn{2}{|c|}{$\begin{array}{l}\text { disposable } \\
\text { protective }\end{array}$} & \multicolumn{2}{|c|}{$\begin{array}{l}\text { disposable } \\
\text { protective }\end{array}$} & \multicolumn{3}{|c|}{ disposable protective } \\
\hline & Gloves & $\begin{array}{c}\text { non- } \\
\text { chemical- } \\
\text { resistant }\end{array}$ & $\begin{array}{c}\text { non- } \\
\text { chemical- } \\
\text { resistant }\end{array}$ & $\begin{array}{l}\text { non- } \\
\text { chemical- } \\
\text { resistant }\end{array}$ & \multicolumn{2}{|c|}{$\begin{array}{l}\text { chemical } \\
\text { resistant }\end{array}$} & \multicolumn{2}{|c|}{$\begin{array}{l}\text { chemical } \\
\text { resistant }\end{array}$} & chemical $r$ & esistant & \multicolumn{3}{|c|}{ chemical resistant } \\
\hline
\end{tabular}




\begin{tabular}{|c|c|c|c|c|c|c|c|}
\hline Task description & $\begin{array}{l}\text { reassembly } \\
\text { of } \\
\text { components } \\
\text { in the plant } \\
\text { and } \\
\text { cleaning } \\
\text { /scraping } \\
\text { operations }\end{array}$ & $\begin{array}{l}\text { dismantling, } \\
\text { solvent- } \\
\text { based } \\
\text { cleaning } \\
\text { and } \\
\text { reassembly } \\
\text { of heating } \\
\text { chamber } \\
\text { elements }\end{array}$ & $\begin{array}{l}\text { dismantling } \\
\text { and } \\
\text { cleaning } \\
\text { gas } \\
\text { injectors, } \\
\text { gas exhaust } \\
\text { valves and } \\
\text { doors }\end{array}$ & $\begin{array}{l}\text { cleaning gas } \\
\text { injectors, } \\
\text { dismantling, } \\
\text { cleaning and } \\
\text { reassembly of } \\
\text { gas exhaust } \\
\text { valves and } \\
\text { pipes, and } \\
\text { cleaning doors } \\
\text { of heating } \\
\text { chambers (dry } \\
\text { wipe and } \\
\text { industrial } \\
\text { vacuum } \\
\text { cleaner) }\end{array}$ & $\begin{array}{l}\text { dismantling, } \\
\text { reassembly and } \\
\text { cleaning } \\
\text { operations } \\
\text { (doors, transfer } \\
\text { cart, ventilator } \\
\text { in the } \\
\text { quenching } \\
\text { chamber etc.), } \\
\text { scraping of the } \\
\text { graphite heating } \\
\text { elements and } \\
\text { cleaning gas } \\
\text { injectors }\end{array}$ & $\begin{array}{l}\text { various reassembly } \\
\text { and cleaning } \\
\text { operations (doors, } \\
\text { transfer cart, etc.), } \\
\text { cleaning gas } \\
\text { injectors followed } \\
\text { by the use of an } \\
\text { industrial vacuum } \\
\text { cleaner, replacement } \\
\text { of graphite heating } \\
\text { elements }\end{array}$ & $\begin{array}{c}\text { carrying out several checks and } \\
\text { dismantling elements outside the } \\
\text { furnace, dismantling of heating } \\
\text { or quenching chambers } \\
\text { elements, doors, process valves } \\
\text { and gas exhaust pipes, } \\
\text { interventions on seals, oil } \\
\text { change }\end{array}$ \\
\hline
\end{tabular}

${ }^{a}$ : CTLF: Central Tunnel Loading Furnace (Figure 1a)

b. FLF: Front Loading Furnace (Figure 1b) 
References to the measurement campaigns are made using the following code: Factory-Year. For example 1-2008 corresponds to the 2008 campaign in factory 1.

\subsection{Air monitoring}

Air samples were taken in the personal breathing zone for each worker, outside the facepiece when respiratory protection equipment (RPE) was worn, over the course of one shift (one 8-h sample) (1-2008, 1-2009, 2-2008, 3-2010 and 3-2011) or two shifts, corresponding to two separate 8-h samples (2-2009 and 4-2012), producing a total of 43 samples (supplementary Table S1). The inhalable fraction was sampled at a flow rate of $1 \mathrm{~L} / \mathrm{min}$ on a $37-\mathrm{mm}$ diameter glass-fibre filter (Whatman GF/C), connected to an XAD-2 purified resin adsorption tube (SIGMA ALDRICH - ORBO ${ }^{\mathrm{TM}} 43$ Supelpak $^{\mathrm{TM}}$ ), in line with the recommendations in the French method (INRS, 2016). BaP and other particulate PAH were trapped on the filter, while the XAD-2 cartridge adsorbed gaseous and semi-volatile PAH. The glass-fibre filter was contained in a closed polystyrene cassette. Air flow was measured by an air flow calibrator using a wet cell method and its stability was checked by comparison of flow-rates at the beginning and end of sampling. After sampling, cassettes and tubes were refrigerated in closed boxes prior to analysis.

After the outer walls of the cassette had been carefully cleaned, the filters were removed and placed in $5 \mathrm{~mL}$ dichloromethane for particle extraction using ultrasound for $15 \mathrm{~min}$. The cassettes were washed with $4 \mathrm{~mL}$ methanol to recover PAH deposited on their inner walls. The two extracts were concentrated by gentle evaporation to dryness under nitrogen flow and the resulting samples were dissolved in at least $500 \mu \mathrm{L}$ of methanol/dichloromethane $(50 / 50)$ and quantified separately. PAH were extracted from the XAD-2 resin with $3 \mathrm{~mL}$ toluene using ultrasound for $15 \mathrm{~min}$. To prevent loss of volatile substances, the extract was analysed without concentration. A $20-\mu \mathrm{L}$ aliquot of the final volume of each extract was injected into a HPLC system and eluted from a Si-C18 column with an acetonitrile/methanol/water mobile phase. $\mathrm{BaP}$ was detected by fluorimetry (Lafontaine et al., 2002) and was quantified by comparison to a seven-point external calibration curve. The limit of detection (LOD) was $0.45 \mathrm{pg}$ $(\mathrm{S} / \mathrm{N}=3)$, which corresponds to a limit of quantification (LOQ) of $1.5 \mathrm{pg}(\mathrm{S} / \mathrm{N}=10)$. For $8-\mathrm{h}$ exposure measured at a flow rate of $1 \mathrm{~L} / \mathrm{min}$, this would correspond to an airborne concentration of $6 \mathrm{pg} / \mathrm{m}^{3}$. 


\subsection{Biomonitoring}

Biomonitoring was performed under the responsibility of the occupational health physician at the different factories investigated. Monitoring started after a two-day period of non-exposure, and lasted a total of 40 hours. All voided urine samples were collected separately, the volume was measured and the sampling time was recorded by INRS. As soon as possible after micturition, four millilitres of each sample were stored in a Uriprel $^{\circledR} \mathrm{PAH}$ cartridge, at the same time, $1 \mathrm{~mL}$ of the same sample was collected on a Uriprel ${ }^{\circledR}$ creatinine cartridge (Simon et al., 2003). 3-OHBaP concentrations were determined using an automated column-switching HPLC system with a fluorescence detector (Simon et al., 2000; Lafontaine et al., 2004). The LOQ was $0.05 \mathrm{ng} / \mathrm{L}$ with an injection sample of $3 \mathrm{~mL}$ hydrolysed urine. The coefficient of variation was less than $5 \%$ for between-day precision when urine samples were spiked with $0.84 \mathrm{ng} / \mathrm{L}, 4.2 \mathrm{ng} / \mathrm{L}$ and $42 \mathrm{ng} / \mathrm{L} 3-\mathrm{OHBaP}$.

To allow statistical analysis of results below the LOQ, we used a 2 -fold lower value. Concentrations were expressed in $\mathrm{nmol} / \mathrm{mol}$ creatinine after normalisation for creatinine concentrations determined using the Jaffé method (Viau et al., 2004). One nmol/mol creatinine corresponds to $2.37 \mathrm{ng} / \mathrm{g}$ creatinine. Some excretion profiles had to be discarded as the 3-OHBaP maximum could not be properly determined. For some operators, two workshifts were monitored, producing two maxima. Table S1 in the online supplementary material lists the number of urinary 3-OHBaP profiles used to determine the maximum 3-OHBaP values. Maximum values were defined as the urine void with the highest metabolite concentration. Some results were very low, mostly for campaign 4-2012. In these cases, it was difficult to determine a $3-\mathrm{OHBaP}$ maximum as values measured for potentially exposed workers were similar to those obtained for smokers (Lafontaine et al., 2006). When this issue arose (10 out of 43), the data were excluded from those used to determine the time at which 3 OHBaP reached its maximum (Table S1). In contrast, all data were considered in the urinary results to reflect the low levels measured for this campaign.

On each excretion profile, the 3-OHBaP maximum was compared to the French BLV of 0.35 nmol/mol creatinine proposed by INRS for samples taken at the beginning of the shift following the shift during which exposure occurred (Lafontaine et al., 2004; Champmartin et al., 2008). Linear Equation 1 describes how external exposure (airborne BaP) correlates with internal dose (urinary 3-OHBaP). This equation was obtained from individual excreted maximal 3-OHBaP concentrations [3-OHBaP] (in $\mathrm{nmol} / \mathrm{mol}$ creatinine) (supplementary Figures S1 and S2) and airborne BaP concentrations [BaP] (in $\mathrm{ng} / \mathrm{m}^{3}$ ) measured in workers' 
personal breathing zones $(n=26)$ in five different working areas where exposure was mainly by the respiratory route (Lafontaine, 2008 updated from Lafontaine et al., 2004).

$[3-\mathrm{OHBaP}]=0.0018[\mathrm{BaP}]+0.0847$

Equation 1

This equation was used to calculate the theoretical maximum urinary 3-OHBaP concentration in $\mathrm{nmol} / \mathrm{mol}$ creatinine which would have been excreted if the operator had actually been exposed to the $\mathrm{BaP}$ airborne concentration measured (in $\mathrm{ng} / \mathrm{m}^{3}$ ) (respiratory exposure only; absence of respiratory protective equipment). For a given measured airborne $\mathrm{BaP}$ concentration, the maximum urinary $3-\mathrm{OHBaP}$ concentration measured was compared to the corresponding theoretical 3-OHBaP concentration.

\section{RESULTS}

\subsection{Airborne BaP measurements}

In all cases, $\mathrm{BaP}$ amounts collected on XAD-2 tubes were below the $\mathrm{LOQ}$, indicating that $\mathrm{BaP}$ was particle-bound and trapped on the filters. The extracts from whole filters and the inner walls of cassettes gave values above the LOQ, and overall airborne BaP concentrations exceeded $1 \mathrm{ng} / \mathrm{m}^{3}$. The median value was $78 \mathrm{ng} / \mathrm{m}^{3}$ (standard deviation [SD]: 2 345; range: 2 $15142 ; n=43)$. The results for the 43 airborne measurements, stratified by year and factory are presented in Figure 2.

The highest results were obtained for campaign 1-2008, whereas the lowest were obtained for campaign 4-2012. 


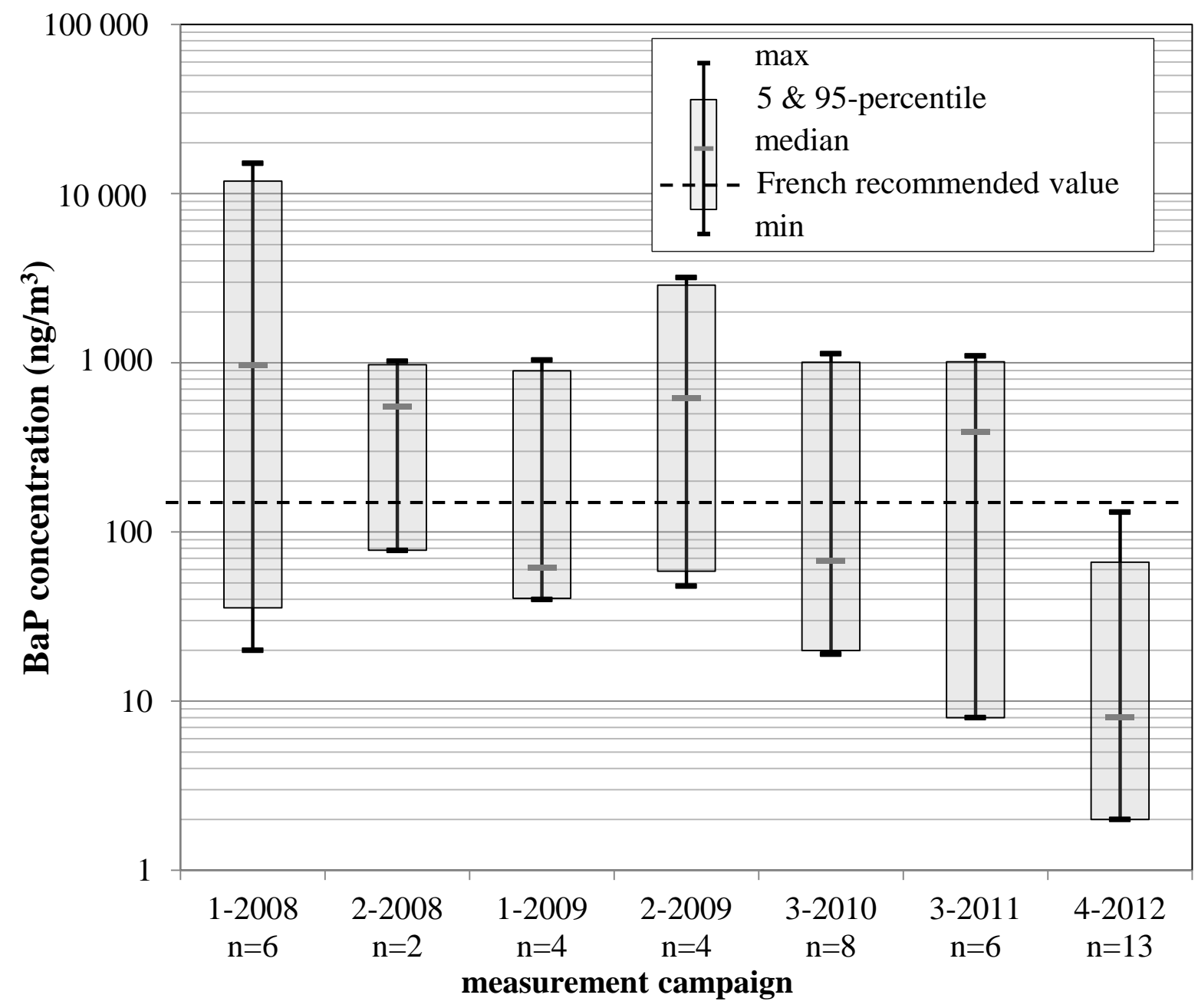

Figure 2: Airborne BaP levels $\left(\mathrm{ng} / \mathrm{m}^{3}\right)$ - $n$ : number of samples. The dotted line indicates the recommended maximum value for French workplaces (CNAMTS): $150 \mathrm{ng} / \mathrm{m}^{3}$

Analysis of these data revealed no obvious decrease in exposure over time. Excluding values from campaigns 1-2008 and 4-2012, most of the results (22 out of 24) were equally distributed below and above the $150 \mathrm{ng} / \mathrm{m}^{3}$ threshold, ranging between 15 and $1500 \mathrm{ng} / \mathrm{m}^{3}$. There was no clear difference between the results obtained for furnaces using propane (12008, 1-2009, 3-2010 and 3-2011) or acetylene (2-2008, 2-2009 and 4-2012) as carburising agent. We detected high concentrations both with CTLF furnaces (1-2008, 1-2009, 3-2010 and 3-2011) and with FLF furnaces (2-2008 and 2-2009).

\subsection{Urinary levels}

The 3-OHBaP excretion profiles established for the furnace maintenance workers were similar to those obtained in other studies with workers from different sectors: artificial target 
factory (Gendre et al., 2002), carbon disc factory (Lafontaine et al., 2004) and electrometallurgy plant (Gendre et al., 2004). As previously observed, urinary concentrations increased steadily after the shift, reaching a maximum at around the beginning of the shift following exposure. Values subsequently decreased (supplementary Figures S1 and S2). On average, for all workers monitored, the 3-OHBaP maximum appeared 17 hours (SD: 4; n=33) after the end of exposure. The 3-OHBaP maxima determined are shown in Figure 3.

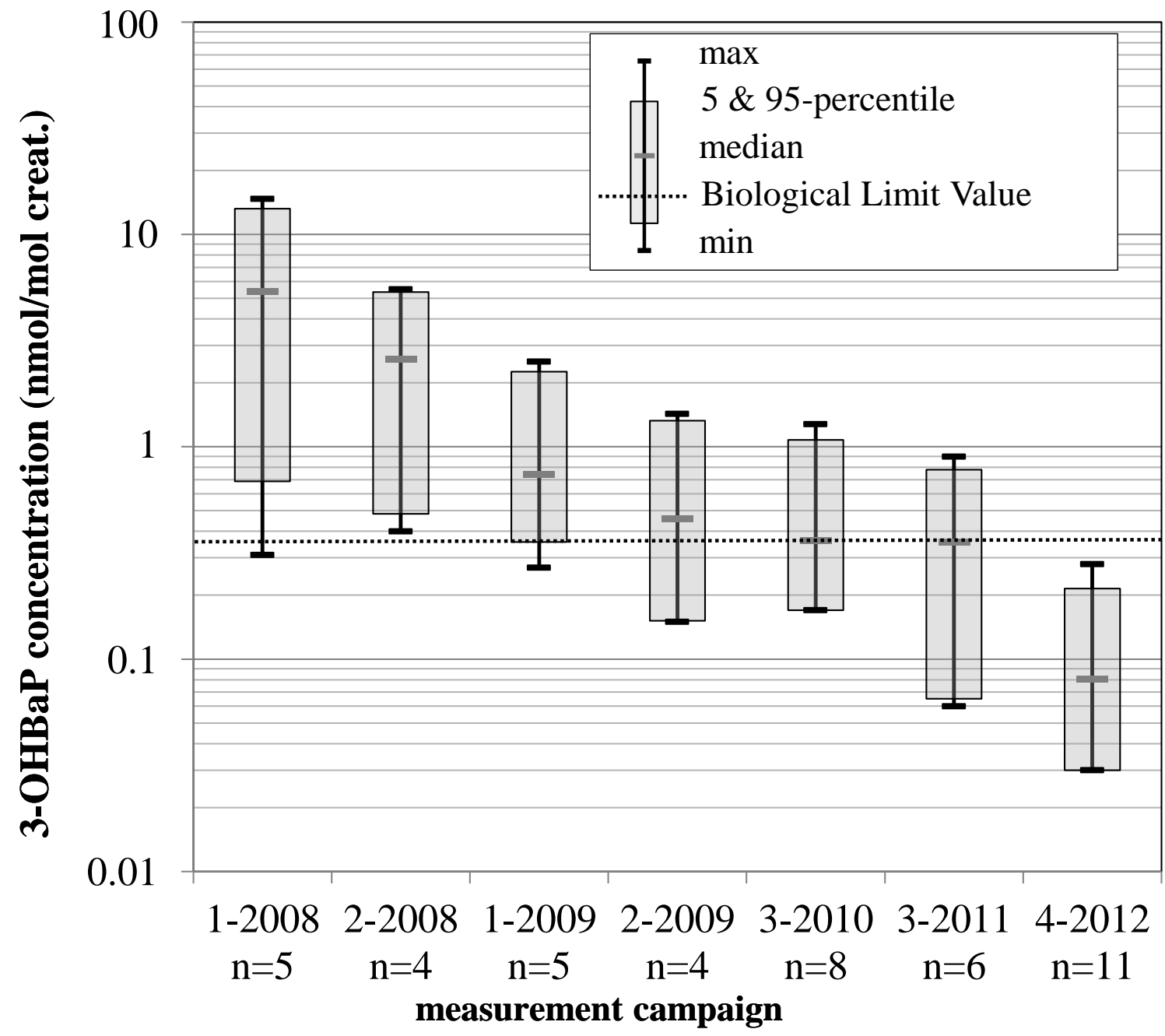

Figure 3: 3-OHBaP maxima (nmol/mol creatinine) determined in workers' urine for the different measurement campaigns - $n$ : number of analyses - The horizontal dotted line indicates the BLV: $0.35 \mathrm{nmol} / \mathrm{mol}$ creatinine.

As for airborne BaP values, the urinary excretion values were extremely variable (median: $0.31 \mathrm{nmol} / \mathrm{mol}$ creatinine; SD: 2.65 ; range: $0.03-14.72 ; \mathrm{n}=43$ ), and the highest urinary levels were recorded during campaign 1-2008 and campaign 2-2008, while the lowest values were 
observed during campaign 4-2012. Almost $75 \%$ of all urinary maxima exceeded the proposed BLV. Nevertheless, in contrast to airborne BaP, in the campaigns from 2008 to 2012 we observed a steady decline in internal exposure levels (as indicated by urinary 3-OHBaP levels).

\subsection{Relationship between airborne and urinary concentrations, penetration routes and use of protective equipment}

Figure 4 shows the 3-OHBaP urinary maximum plotted against the airborne $\mathrm{BaP}$ concentration. This Figure includes data from all campaigns. The theoretical maximum 3$\mathrm{OHBaP}$ values were calculated using Equation 1 with the airborne $\mathrm{BaP}$ values and were represented by the continuous curve. The standard error of the estimate is represented by the two dotted curves, determined by calculating the standard deviation on the absolute values of the differences between the experimental 3-OHBaP results and the theoretical values obtained by applying Equation 1 (Lafontaine et al., 2008). This standard error is an indicator of the uncertainty of the values predicted by Equation 1. Equation 1 was derived from data on exposure assessed in different working conditions, from several different workplaces and different cohorts. This uncertainty could be explained by a number of parameters: uncertainties in measurements and analysis, inter-individual metabolic variability, etc. To avoid misclassification of penetration routes, only data located outside the two dotted curves will be commented on here.

To obtain a clear presentation of the data as a whole, log-scale axes were used. Values higher than $5000 \mathrm{ng} / \mathrm{m}^{3}$ (1 out of 35) and lower than $10 \mathrm{ng} / \mathrm{m}^{3}$ (7 out of 35) were omitted; thus, only 27 of the 35 paired values (Table S1) are represented in Figure 4. 


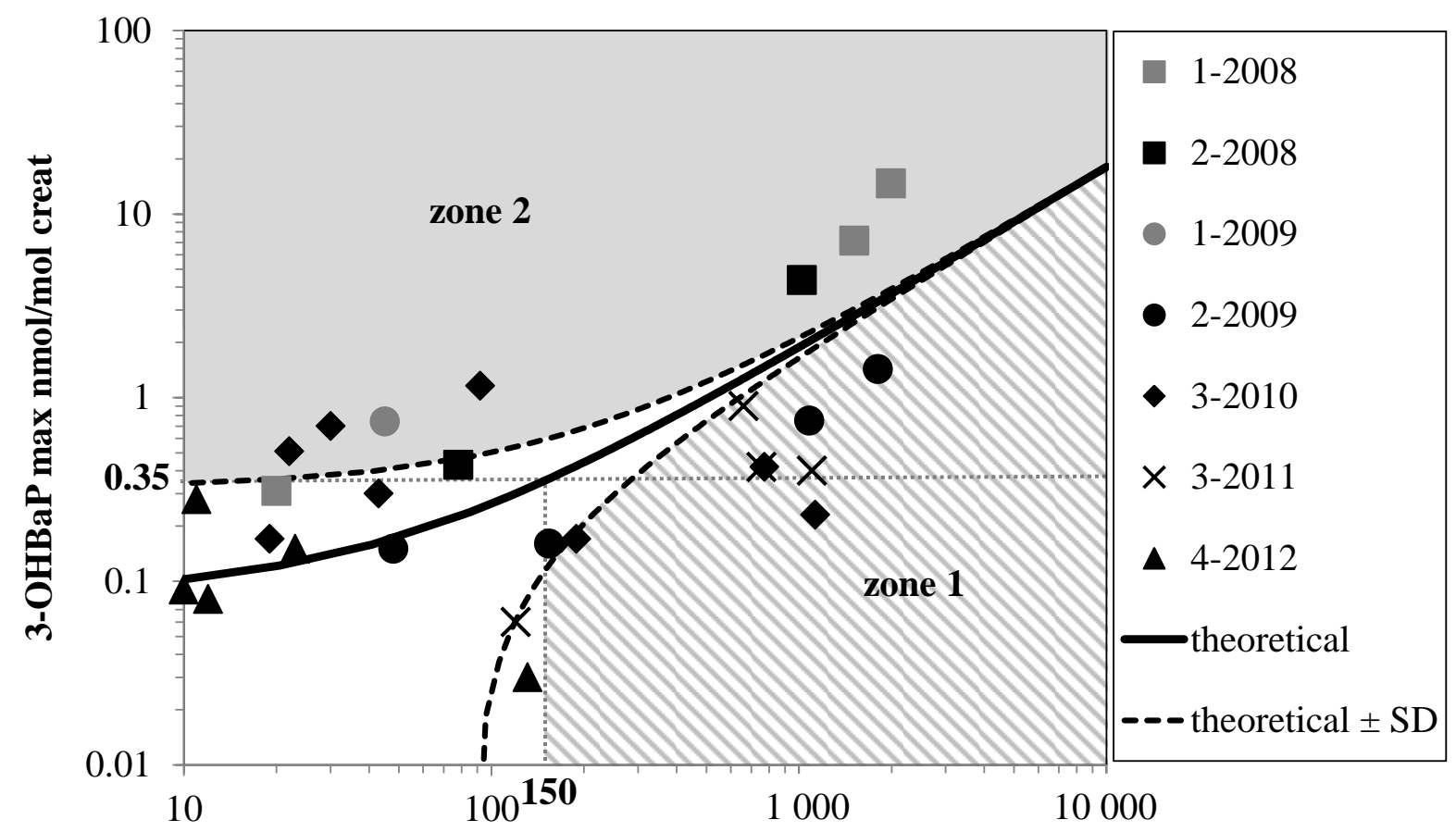

Airborne BaP ng/m3

Figure 4: Maximum urinary 3-OHBaP concentrations plotted against airborne BaP concentrations measured during the seven sampling campaigns. Continuous line (一): theoretical 3-OHBaP maxima; Dashed line (---): standard error of estimation of 3-OHBaP maxima - For the description of "zone 1" and "zone 2" please refer to the text.

For the campaigns performed from 2008 to 2011, most of the 3-OHBaP values exceeded the proposed BLV even when the airborne concentrations were lower than $150 \mathrm{ng} / \mathrm{m}^{3}$. This result suggests that operators were potentially exposed through both the skin and the airways. Figure 4 attempts to elucidate the contributions of these penetration routes and also provides information on the efficiency of the personal protective equipment (PPE) used.

Zone 1 (hatched area) indicates airborne BaP values exceeding $150 \mathrm{ng} / \mathrm{m}^{3}$ associated with 3OHBaP values falling below the lower dotted curve, which represents the theoretical 3$\mathrm{OHBaP}$ values minus the standard error of the estimate. Operators wore RPE (except during campaigns 1-2008 and 2-2008), and we must assume that the equipment was worn correctly. In these conditions, workers will not have been exposed to the high $\mathrm{BaP}$ concentrations measured. The 3-OHBaP values which were close to or higher than the French BLV may therefore be explained by a dermal route of exposure. The extent of airborne exposure contributing to the values measured would depend on the RPE's efficiency and how it was used. Even with airborne concentrations close to $1000 \mathrm{ng} / \mathrm{m}^{3}$, real operator exposure (indicated by the 3-OHBaP concentration measured) may be close to or lower than the BLV, 
thanks to the use of appropriate PPE, in particular RPE. Indeed, BaP is known to be trapped by both $\mathrm{P} 2$ and P3-type masks.

Zone 2 (grey area) corresponds to measured 3-OHBaP values exceeding the theoretical maxima plus the standard error of the estimate (above the upper dotted curve). Values in this zone suggest a dermal route of exposure for these workers. The difference between measured and calculated values is particularly marked for workers operating in an atmosphere where airborne $\mathrm{BaP}$ concentrations were low (lower than the recommended maximum limit for France) as indicated by the three diamond-shaped symbols (campaign 3-2010). Actual 3$\mathrm{OHBaP}$ values for these workers can be up to $1 \mathrm{nmol} / \mathrm{mol}$ creatinine, which is equivalent to three times the BLV. For data points in this zone, whatever the airborne BaP concentration, when an operator's 3-OHBaP concentration lies above the upper dotted curve it indicates that dermal protections must have failed or may not have been used. This is a matter for concern as the urinary values exceeded the BLV.

\section{Discussion}

For all campaigns except those performed in 2008, workers wore protective masks. Thus, inhalation exposure would have been much lower than suggested by the airborne $\mathrm{BaP}$ concentrations measured. The actual exposure levels when workers used RPE depend on filter efficiency, leakage, face shape and how the mask was worn.

Until 2008, knowledge of PAH exposure during maintenance operations in carburising furnaces was limited. Consequently, in the two first campaigns, operators worked without applying any particular safety precautions, and this ignorance of the risks explains the high airborne and urinary concentrations. Overall in this study, almost 35\% of the airborne values were above the recommended value for France, but for campaign 4-2012 all the results were lower.

In several cases, two consecutive campaigns were performed in the same plant. Although operators were more aware of the presence of PAH during the second campaign, the second sets of airborne levels were not always decreased compared to the first. Broad scattering of the airborne results was observed even within a single campaign. Thus, atmospheric BaP concentrations seem to depend more on occupational activities, which can be different from one individual to another, even on the same site. As the cleaning and maintenance operations were manually performed, worker behaviour and method may also have influenced results. 
Another possible explanation for the large range of different airborne $\mathrm{BaP}$ concentrations could lie in variations in concentration within residues (supplementary Section S3).

Indeed, the $\mathrm{BaP}$ concentrations in solid deposits were not all equivalent, and - as might be expected - operations carried out in proximity to high-concentration residues generated high airborne BaP concentrations. For example, the highest airborne values in campaign 3-2010 (exceeding $150 \mathrm{ng} / \mathrm{m}^{3}$ ) were produced in these conditions. In addition, operator movement could cause particles from previous cleanings and scraping to become airborne once again, particularly in the polluted central tunnel. This was the case in campaign 1-2008, where the highest airborne $\mathrm{BaP}$ values were measured during the final cleaning operations and reassembly, involving numerous passages through the central tunnel. Thus, the operator's main activity could explain high airborne levels. Importantly, it should be noted that high airborne concentrations were not always associated with visible dust emissions.

Except for campaign 4-2012, all urinary values were much higher than the mean values determined for smokers $(0.03 \mathrm{nmol} / \mathrm{mol}$ creat.; Lafontaine et al., 2006). The contribution of cigarette smoke to urinary 3-OHBaP concentrations was marginal (Förster et al., 2008), we therefore chose not to distinguish between data for smokers and non-smokers. As mentioned above, since 2008 awareness of the risks of PAH exposure has been raised among workers, and as a result appropriate PPE are now used and operations are better managed. These modifications have resulted in an overall decrease in exposure levels, as reflected by urinary concentrations, although conditions were different between campaigns (plant, activities, airborne BaP levels, etc.). As shown in Figure 3, the decrease was pronounced between 2008 (no knowledge of the presence of PAH and absence of PPE) and 2009 (PAH pollution known and PPE used), but was much smaller for subsequent years. Although some individual values still exceeded the BLV, median values were equivalent to it for campaigns 3-2010 and 3-2011 and were lower than it for campaign 4-2012.

The temporal trends for the airborne $\mathrm{BaP}$ concentrations and maximal 3-OHBaP concentrations measured were completely different. Between 2008 and 2012, median airborne $\mathrm{BaP}$ values followed a switchback trend whereas the 3-OHBaP data followed a decreasing trend. This difference could be due to the fact that high-concentration BaP deposits (Section S3) were present during all campaigns, and that even the most cautious operator will probably trigger dust emissions, thus producing high airborne $\mathrm{BaP}$ values. This scenario is all the more likely as an operator cannot tell by looking at black deposits whether they contain high levels of $\mathrm{BaP}$ or not. When operators wore appropriate respiratory and dermal protection, urinary 
levels close to or below the BLV could be measured even when airborne concentrations were high.

Even when the results for the workers monitored are considered individually, there is no direct and clearly identified relationship between the airborne and urinary data.

This lack of relationship is probably because measurement of the airborne concentration overestimates inhalation exposure for a worker wearing RPE and because it only assesses potential inhalation exposure while ignoring potential absorption through the skin. During campaign 3-2010 (Figure 4) the workers with the highest airborne data, above the recommended value for French workers, did not excrete the highest 3-OHBaP maxima (diamond-shaped symbols in zone 1, Figure 4). In contrast, some workers exposed to lower airborne concentrations excreted 3-OHBaP concentrations exceeding the BLV (diamondshaped symbols in zone 2, Figure 4). This result could be explained by differences in RPE (Table 1). However, on closer examination it appeared that the two workers for whom the highest airborne results and low urinary results were measured were equipped with lowergrade respiratory protective equipment, suggesting that exposure occurred by a cutaneous route for the other workers. For these workers, "dirty black marks" had been observed on their hands and dermal swabbing (not shown) highlighted more extensive skin contamination.

It is not easy to compare the data presented here with data published for other work areas because of differences in study design, material, methods and sampling protocols. In addition, the preventive measures applied are not always specified in publications (Hopf et al., 2009). Moreover, significant variability in the levels detected was observed in the present study.

PAH exposure has previously been assessed for workers in converter infeed, production of refractory products, coking plants and graphite electrodes. Förster et al. (2008) found higher median and maximum values for airborne BaP than those presented here. However, their 3$\mathrm{OHBaP}$ values were in the same range as ours, with a median of $0.54 \mathrm{nmol} / \mathrm{mol}$ creatinine for workers producing graphite electrodes. The highest value they measured was $8.24 \mathrm{nmol} / \mathrm{mol}$ creatinine, almost 2-fold lower than our highest value. However, Förster et al., 2008 analysed 3-OHBaP in post-shift spot urine samples, while we report maximum 3-OHBaP concentrations, measured on average 17 hours post-exposure. As we collected all urine between shifts, we can affirm that the maximum levels were considerably higher than concentrations measured immediately post-shift. During electrode production, Barbeau et al. (2015) found similar median airborne and urinary values to ours; however, in each case the maximum of the range they reported was considerably lower than our values. Comparison 
with these two studies shows that real exposure of workers operating low-pressure carburising furnaces could be at least equivalent to or even higher than the exposure levels reported for other industrial workplaces known to produce high levels of exposure to $\mathrm{PAH}$ and $\mathrm{BaP}$. Similar to what we report here, in these two previous studies, a poor correlation was found between airborne $\mathrm{BaP}$ levels and corresponding urinary levels. This discrepancy was attributed to dermal exposure, although this exposure route was never measured. Indeed, the relative contributions of dermal and inhalation exposure are not easy to estimate. In the aluminium industry, the two exposure routes were distinguished by measuring levels of pyrene and its metabolite 1-hydroxypyrene and using an experimental setup distinguishing between workers using dermal protection and workers equipped with RPE (Lafontaine et al., 2002). The results presented help to estimate the relative contribution of the two penetration routes, indicating that dermal exposure contributed less than $50 \%$ to overall exposure in this case. In our study workers either wore no protective equipment or were equipped with both respiratory and cutaneous protection devices; it was therefore not possible to assess the relative contribution of the different routes of penetration by a method similar to that described by Lafontaine et al. (2002). In the present study, the exposure routes appear to vary depending on the activities performed and the PPE used. A dermal route of exposure is suggested by data in Figure 4 located in zone 2, and this appears to be the main penetration route for workers fitted with RPE. Results from dermal swabbing (not shown) confirmed that furnace maintenance workers' skin was contaminated with PAH.

Several other studies have reported dermal absorption of PAH based on various experiments. In two recent reports (Baxter et al., 2014; Fent et al., 2014), skin swabs indicated dermal contamination (mainly on the neck) in fire-fighters; this contamination was associated with measurable urinary concentrations, suggesting skin absorption as a potential route of exposure. In a study of roofers (Serdar et al., 2012), a negative association was found between glove use and levels of a biomarker for DNA damage, and a positive correlation was found between burns sustained during work and a urinary metabolite of PAH, indicating that dermal absorption was a significant route of exposure. Levels of urinary PAH biomarkers measured at bedtime were found to correlate with dermal patch-based measurement of PAH exposure in asphalt-exposed workers, indicating that dermal contact persists after a work shift (Sobus et al., 2009).

Whatever the distribution between the two penetration routes, they must be given equal consideration by industrial hygienists. To limit both respiratory and dermal uptake, hygienists 
recommend suppressing or reducing emissions. In the case of carburising furnaces, this could be done by targeting and minimising critical situations: for example, avoiding unnecessary cleaning, using a vacuum cleaner with HEPA filter, damp wipes to clean dusty deposits from surfaces, etc. In addition, local exhaust ventilation during operations generating dust could be envisaged (INRS, 2015) and, where necessary, appropriate protective equipment should also be added. Dermal exposure can also be linked to direct contamination (contact with dirty marks, involuntary staining due to reflex reactions, "insidious" pollution), to contact with polluted tools, soiled factory areas or with soiled protective equipment, etc., which is more difficult to prevent. The use of appropriate clean protective clothing, particularly gloves, is therefore necessary. Indeed, in our study it emerged that some workers did not wear gloves, removed them during their shift, wore contaminated gloves, or that some parts of their bodies (for example wrists, hands and/or face) came into contact with BaP-rich solid deposits. These observations suggest a need to reinforce communication on the dermal route of exposure as dermal contact, even with a small amount of soilage, could explain why many urinary values exceeded the proposed BLV.

The use of propane has been reported to be a source of technical problems because of the uncontrolled formation of tars and soot (Bruce et al., 2006), and acetylene is widely recommended as a solution to these problems (Bruce et al., 2006; Qin, 2008; Herring, 2012). However, with regard to PAH exposure, we found no clear difference between the two hydrocarbons (Figure 2 and supplementary Section S3). Additional samples from factory 2 and from three supplementary workplaces where acetylene was used with a CTLF furnace (data not shown), confirmed the presence of high levels of $\mathrm{BaP}$ (several $\mathrm{g} / \mathrm{kg}$ ) in setups using this hydrocarbon.

Similarly, furnace design (CTLF or FLF) does not seem to contribute to differences in exposure levels. However, the installation in factory 4 has airtight doors between the heating chambers and the tunnel. Consequently, the gases were exclusively evacuated through the gas outlet located in the heating chambers. Although deposits were still found, they were confined to a smaller area, and the tunnel and the transfer cart were cleaner in factory 4 than in the other factories studied. This more confined soilage could be one of the reasons why very low exposure levels were detected during campaign 4-2012.

Furthermore, the amount of PAH formed and thus the occupational exposure could be reduced by studying the influence of the operating parameters: temperature, pressure and gas residence time as a wide variety of molecules react with each other to form PAH and their 
precursors (Richter et al., 2000). Above $180{ }^{\circ} \mathrm{C}, \mathrm{BaP}$ is in a gaseous state (IWAIR, 1998) or in the form of chemical precursors. Thus, no solid BaP deposit can be formed in the heating cell at these temperatures; only when temperatures decrease - at the reactor outlet - do BaP and other PAH become liquid or solid.

The detailed kinetic mechanisms of PAH formation has been studied (Norinaga et al., 2006, 2009), and the results presented suggest that it would be preferable to work at low-pressure and at temperatures around $800{ }^{\circ} \mathrm{C}$. Vacuum carburising processes could also be carried out by several successive carbon enrichment and diffusion phases using nitrogen which should reduce the amount of PAH generated (Goldsteinas and Pelissier, 2002). Post-pyrolysis treatment could also be considered as a means to remove the PAH, e.g. catalytic filter (Mastral et al., 1999; Liljelind et al., 2001; Aranda et al., 2012) or gas-liquid absorption (Baudry et al., 2002). Furthermore, solids (soot, tar, PAH) should always be separated from the gas phase as close as possible to the furnace as it reduces the risk of exposure to PAH during maintenance operations.

\section{Conclusions}

Low-pressure carburising treatment was introduced to replace atmospheric pressure carburising because the latter generated toxic and environmentally dangerous compounds like $\mathrm{CO}_{2}$ and $\mathrm{CO}$. The low-pressure version of the technique offers numerous technical advantages: it improves carbon penetration and thus the quality of the steel parts treated, it prevents the formation of $\mathrm{CO}_{2}$ and surface oxidation due to the absence of oxygen, and it increases the molecular diffusion of gas. The technological success of this technique has led to the installation of more than six hundred low-pressure carburising chambers worldwide to date, mainly using propane and acetylene as carburising gas (Prunel and Stauder, 2005). This article is the first report on occupational exposure to carcinogenic substances during maintenance operations performed in these furnaces. In the absence of preventive measures and without protective equipment, the French recommendation for atmospheric BaP levels and the French BLV were considerably exceeded. Informed operators who used appropriate PPE received markedly lower exposure to $\mathrm{BaP}$. Despite an overall decrease in exposure levels, many operators still excreted 3-OHBaP levels exceeding the BLV, even when low airborne $\mathrm{BaP}$ concentrations were measured. The approach used, monitoring airborne $\mathrm{BaP}$ concentrations and 3-OHBaP excretion, and comparing measured and theoretical 3-OHBaP concentrations, provided information on the main route of exposure. For several workers, 
dermal contamination appeared to be the main persistent exposure route despite improvements to procedures and protection. Work on other preventive practices, in particular on the process will therefore be necessary.

\section{Conflict of interest}

This study was fully funded by INRS, employer of all the researchers involved. The authors declare no conflict of interest.

\section{References}

AFNOR. European standard AFNOR (2006) Respiratory protective devices Recommendations for selection, use, care and maintenance, NF EN 529- ISSN 0335-3931. La Plaine Saint-Denis: AFNOR.

Aranda A, Murillo R, García T, Mastral AM. (2012) Simulation and optimization of tyrebased steam activated carbons production for gas-phase polycyclic aromatic hydrocarbons abatement. Chemical Engineering Journal 187, 123- 132.

Barbeau D, Lutier S, Bonneterre V, Persoons R, Marques M, Hervé C, Maitre A. (2015) Occupational exposure to polycyclic aromatic hydrocarbons: relations between atmospheric mixtures, urinary metabolites and sampling times. Int. Arch. Occup. Environ. Health; 88: 1119-1129.

Barbeau D, Persoons R, Marques M, Hervé C, Laffitte-Rigaud G, Maitre A. (2014) Relevance of urinary 3-hydroxybenzo[a]pyrene and 1-hydroxypyrene to assess exposure to carcinogenic Polycyclic Aromatic Hydrocarbon in metallurgy workers. Ann. Occup. Hyg.; 58 (5): 579-590.

Barbeau D, Maître A, Marques M. (2011) Highly sensitive routine method for urinary 3hydroxybenzo[a]pyrene quantitation using liquid chromatography-fluorescence detection and automated off-line solid phase extraction. Analyst; 136: 1183-1191.

Baudry Y., Lambert JP, Delperier B, Potin JF. (2002) Procédé et installation pour le traitement de gaz effluent contenant des hydrocarbures. Patent CA 2469330 A1.

Baxter CS, Hoffman JD, Knipp MJ, Reponen T, Haynes EN. (2014) Exposure of firefighters to particulates and polycyclic aromatic hydrocarbons. Journal of Occupational and Environmental Hygiene; 11: D85-D91. 
Bruce S, Cheetham V, Stratton PF. (2006) Low-pressure carburizing systems: a review of current technology. Berg- and Hüttenmännische Monatschefte; 151 (11): 451-456.

Champmartin C, Jeandel F, Lafontaine M, Simon P. (2008) HAP: Méthodes d'échantillonnage et d'analyse en surveillance biologique de l'exposition. Bulletin d'Information en Santé Environnementale, Institut de Santé Publique du Québec; 19 (5): 9-11.

Caisse Nationale d'Assurance Maladie des Travailleurs Salariés (CNAMTS). (1984) Recommendations R235 and R245, ISSN 0373-1944. Paris: INRS.

Coppin P, Lhote B, Buffin M, Cantacuzène S. (2000) Atmosphères de traitement thermique. TechIng; M1220; 1-29.

Dulcy J, Gantois M. (2007) Théorie des traitements thermochimiques - Cémentation. Carburation. Tech Ing; M1222: 1-23.

Fent KW, Eisenberg J, Snawder J, Sammons D, Pleil JD, Stiegel MA, Muelleer C; Horn GP, Dalton J. (2014) Systemic exposure to PAHs and benzene in firefighters suppressing controlled structure fires. Ann. Occup. Hyg.; 58(7): 830-845.

Förster K, Preuss R, Rossbach B, Brüning T, Angerer J, Simon P. (2008) 3Hydroxybenzo[a]pyrene in the urine of workers with occupational exposure to polycyclic aromatic hydrocarbons in different industries. Occup. Environ. Med.; 65(4): 224-229.

Gendre C, Lafontaine M, Delsaut P, Simon P. (2004) Exposure to polycyclic aromatic hydrocarbons and excretion of urinary 3-hydroxybenzo[a]pyrene: assessment of an appropriate sampling time. Polycyclic Aromatic Compounds; 24: 433-439.

Gendre C, Lafontaine M, Morele Y, Payan JP, Simon P. (2002) Relationship between urinary levels of 1-hydroxypyrene and 3-hydroxybenzo[a]pyrene for workers exposed to polycyclic aromatic hydrocarbons. Polycyclic Aromatic Compounds; 22:761-779.

Goldsteinas A, Pelissier L. (2002) Procédé de cémentation basse pression. Patent WO 02/068707 A1.

Gündel J, Schaller KH, Angerer J. (2000) Occuoational exposure to polycyclic aromatic hydrocarbons in a fireproof stone producing plant: biological monitoring of 1-hydroxypyrene, 1-,2-,3- and 4-hydroxyphenanthrene, 3-hydroxybenz(a)anthracene and 3hydroxybenzo(a)pyrene. Int Arch Occup Environ Health; 73: 270-274. 
Herring DH. (2012) A case for acetylene based low pressure carburizing of gears. Thermal Processing; 40-46.

Hopf NB, Carreon T, Talaska G. (2009) Biological markers of carcinogenic exposure in the aluminum smelter industry-A systematic review. Journal of Occupational and Environmental Hygiene; 6: 562-581.

IARC. (2012) Monography - Monographs on Chemical agents and related occupations - A review of human carcinogens. Volume 100F. Lyon: International Agency for Research on Cancer.

Institut national de recherche et de sécurité (INRS). (2015) Principes généraux de ventilation, ED 695. Guide de ventilation. Available at : http://www.inrs.fr/header/recherche.html?queryStr=guide+de+ventilation\&rechercher=OK. Accessed 12 December 2016.

Institut national de recherche et de sécurité (INRS). (2016) Hydrocarbures Aromatiques Polycycliques (HAP), method M-332. Base de données MetroPol. Available at: http://www.inrs.fr/publications/bdd/metropol/fiche.html?refINRS=METROPOL_332.

Accessed 12 December 2016.

IWAIR (1998) Technical Background Document - Appendix B. Washington, DC: United States Environmental Protection Agency Office of Solid Waste. 20460 EPA 530-R-99-004 December 1998.

Lafontaine M. (2008) Utilisation des métabolites urinaires pour l'estimation et la prévention du risque HAP. BISE, Institut de Santé Publique du Québec; 19 (5): 32-35.

Lafontaine M, Champmartin C, Simon P, Delsaut P, Funck-Brentano C. (2006) 3Hydroxybenzo[a]pyrene in the urine of smokers and non-smokers. Toxicology Letters; 162: 181-185.

Lafontaine M, Gendre C, Delsaut P, Simon P. (2004) Urinary 3-hydroxybenzo[a]pyrene as a biomarker of exposure to polycyclic aromatic hydrocarbons : an approach for determining a biological limit value. Polycyclic Aromatic Compounds; 24: 441-450.

Lafontaine M, Gendre C, Morele Y, Laffitte-Rigaud G. (2002) Excretion of urinary 1hydroxypyrene in relation to the penetration routes of polycyclic aromatic hydrocarbons. Polycyclic Aromatic Compounds; 22: 579-588. 
Liljelind P, Unsworth J, Maaskant O, Marklund S. (2001) Removal of dioxins and related aromatic hydrocarbons from flue gas streams by adsorption and catalytic destruction. Chemosphere; 42: 615-623.

Lutier S, Maître A, Bonneterre V, Bicout DJ, Marques M, Persoons R, Barbeau D. (2016) Urinary elimination kinetics of 3-hydroxybenzo(a)pyrene and 1-hydroxypyrene in a prebake aluminium electrode production plant : Evaluation of diuresis correction methods for routine biological monitoring. Environmental Research; 147: 469-479.

McClean MD, Rinehart RD, Ngo L., Eisen EA, Kelsey KT, Wiencke JK, Herrick RF. (2004) Urinary 1-hydroxypyrene and polycyclic aromatic hydrocarbon exposure among asphalt paving workers. Ann. Occup. Hyg.; 48 (6): 565-578.

Mastral AM, Callén MS, Murillo R, García T. (1999) Polycyclic aromatic hydrocarbons and organic matter associated to particulate matter emitted from atmospheric fluidized bed coal combustion. Environ. Sci. Technol.; 33: 3177-3184.

Norinaga K, Deutschmann O, Saegusa N, Hayashi J. (2009) Analysis of pyrolysis products from light hydrocarbons and kinetic modeling for growth of polycyclic aromatic hydrocarbons with detailed chemistry. J. Anal. Appl. Pyrolysis; 86: 148-160.

Norinaga K, Deutschmann, O, Hüttinger KJ. (2006) Analysis of gas phase compounds in chemical vapor deposition of carbon from light hydrocarbons. Carbon; 44, 9: 1790-1800.

Prunel G, Stauder B. (2005) The advantages of low pressure carburizing in the heat treatment subcontracting business. Proceeding on the $14^{\text {th }}$ IFHTSE congress; $1: 364-369$.

Qin M. Vacuum carburizing and high pressure gas quenching technology in automotive industry (2008). Int Heat Treat Surf Eng; 2 (3/4): 116-120.

Richter H, Howard JB. (2000) Formation of polycyclic aromatic hydrocarbons and their growth to soots-a review of chemical reaction pathways. Progr. Energy Combust. Sci.; 26: 565-608.

Scheepers PTJ, van Houtum J, Anzion RBM, Champmartin C, Herlsenberg S, Bos RP, van der Valk P. (2009) The occupational exposure of dermatology nurses to polycyclic aromatic hydrocarbons-evaluating the effectiveness of better skin protection. Scand. J. Work Environ. Health; 35(3): 212-221. 
Serdar B, Lee D, Dou Z. (2012) Biomarkers of exposure to polycyclic aromatic hydrocarbons (PAHs) and DNA damage: a cross-sectional pilot study among roofers in South Florida. BMJ Open; 2(4): 1-10.

Simon P, André F, Delsaut P, Kivistö H, Gendre C, Fabre N, Lafontaine M, Laroche M, Nicot T, Park I, Reiser T, Salignac P, Stines A. (2003) Surveillance biologique : vers un nouveau dispositif de recueil urinaire. DMT; 93: 35-60.

Simon P, Lafontaine M, Delsaut P, Morele Y, Nicot T. (2000) Trace determination of urinary 3-OHBaP by automated column-switching high performance liquid chromatography. J. Chromatography B; $748: 337-348$.

Sobus JR, McClean MD, Herrick RF, Waidyanatha S, Nylander-French LA, Kupper LL, Rappaport SM. (2009) Comparing urinary biomarkers of airborne and dermal exposure to polycyclic aromatic compounds in asphalt-exposed workers. Ann. Occup. Hyg.; 53(6): 561571.

Van Rooij JGM, Bodelier-Bade MM, Jongeneelen FJ. (1993) Estimation of individual dermal and respiratory uptake of polycyclic aromatic hydrocarbons in 12 coke oven workers. Br. J. Ind. Med.; 50: 623-632.

Van Rooij JGM. (1994) dermal exposure to polycyclic aromatic hydrocarbons among workers. Doctoral thesis. Nijmegen: Katholieke Universiteit Nijmegen.

Viau C, Lafontaine M, Payan JP. (2004) Creatinine normalization in biological monitoring revisited: the case of 1-hydroxypyrene. Int. Arch. Occup. Environ. Health; 77: 177-185. 
Supplementary material for:

"Maintenance of low-pressure carburizing furnaces: a source of PAH exposure"

Catherine Champmartin, Fanny Jeandel, Hubert Monnier

This document includes (6 pages):

Section S1: with Table S1. Number of airborne and urinary samples used for the final analysis (p. S2)

Section S2: with Figure S1. Urinary 3-OHBaP profile (worker D, campaign 1-2008) (p. S3)

and with Figure S2. Urinary 3-OHBaP profile (worker A, campaign 1-2009) (p. S3)

Section S3: Analysis of residues (p. S4-S5) with Table S2. Overview of the BaP concentrations in the various samples collected during campaigns in factories 1 and 3 (CTLF furnace using propane) and factory 4 (CTLF furnace using acetylene).

Section S4: References (p.S6) 


\section{Section S1}

Table S1. Number of airborne and urinary samples used for the final analysis

\begin{tabular}{|c|c|c|c|c|c|}
\hline Campaign & $\begin{array}{l}\text { Number of } \\
\text { workers } \\
\text { monitored }\end{array}$ & $\begin{array}{l}\text { Number of } \\
\text { airborne } \\
\mathrm{BaP} \\
\text { samples }\end{array}$ & $\begin{array}{l}\text { Number of } \\
\text { urinary } \\
\text { maximum } \\
\text { 3-OHBaP } \\
\text { samples }\end{array}$ & $\begin{array}{l}\text { Number of } \\
\text { paired } \\
\text { airborne and } \\
\text { urinary } \\
\text { samples }\end{array}$ & $\begin{array}{l}\text { Number of urinary } \\
\text { profiles used to } \\
\text { determine time of } \\
\text { 3-OHBaP } \\
\text { maximum }\end{array}$ \\
\hline $1-2008$ & 6 & 6 & 5 & 4 & 5 \\
\hline $2-2008$ & 2 & 2 & 4 & 2 & 4 \\
\hline $1-2009$ & 4 & 4 & 5 & 1 & 5 \\
\hline $2-2009$ & 2 & 4 & 4 & 4 & 4 \\
\hline $3-2010$ & 8 & 8 & 8 & 8 & 8 \\
\hline $3-2011$ & 8 & 6 & 6 & 5 & 4 \\
\hline $4-2012$ & 7 & 13 & 11 & 11 & 3 \\
\hline
\end{tabular}




\section{Section S2}

\section{Urinary 3-OHBaP profiles}

The excretion profiles (Figures S1 and S2) show how 3-OHBaP concentrations change with time over the collection period. Shift times are indicated in grey. The dotted horizontal line represents the $\mathrm{BLV}(0.35 \mathrm{nmol} / \mathrm{mol}$ creatinine $)$. Each square represents the $3-\mathrm{OHBaP}$ concentration measured in an individual urine sample.

Figure S1. - Urinary 3-OHBaP profile (worker D, campaign 1-2008). The 3-OHBaP maximum measured was $7.15 \mathrm{nmol} / \mathrm{mol}$ creatinine and occurred 18 hours after the end of the first shift.

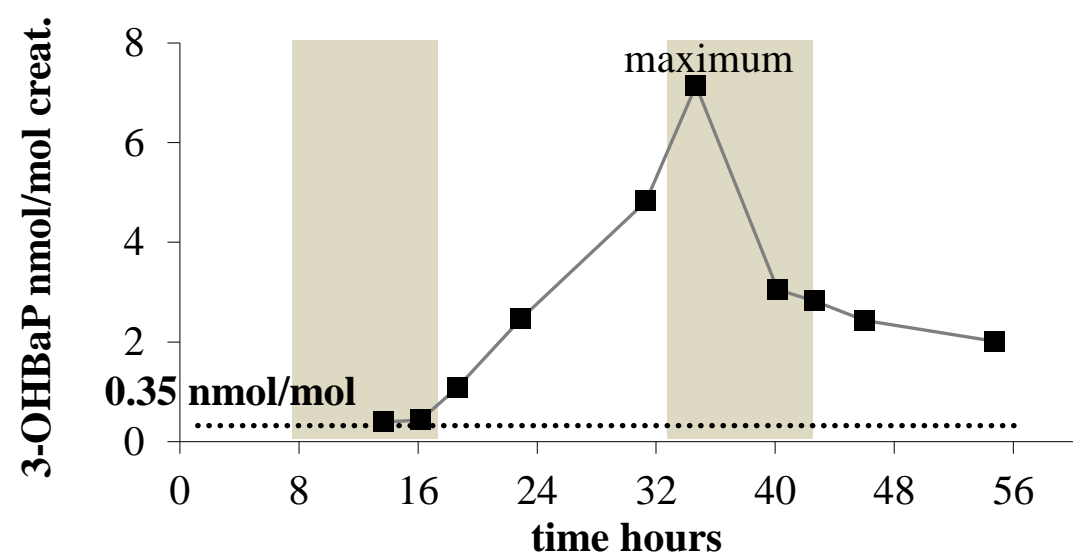

Figure S2. - Urinary 3-OHBaP profile (worker A, campaign 1-2009). The 3-OHBaP maximum measured was $0.70 \mathrm{nmol} / \mathrm{mol}$ creatinine and occurred 16.5 hours after the end of the first shift.

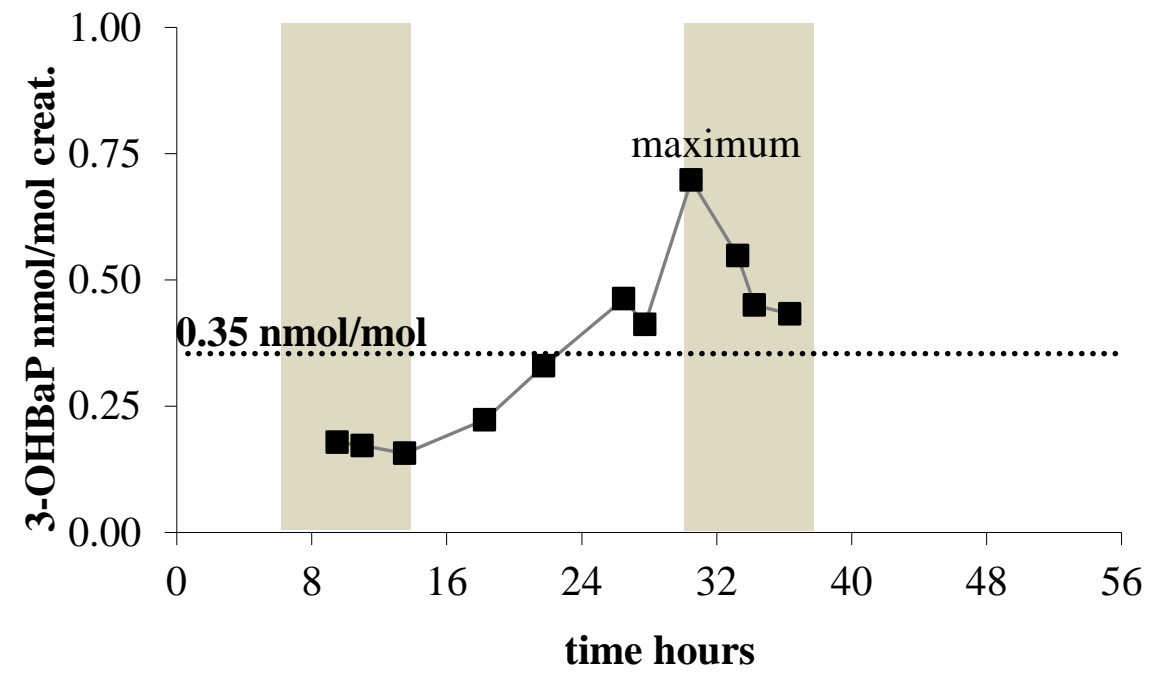




\section{Section S3: Residues analysis}

\section{Material and methods}

Deposits of by-products were sampled in various locations within furnaces, generally with a spatula by scraping the deposit from a surface and transferring it to a vial. After dilution in an appropriate solvent (tetrahydrofuran, dichloromethane, etc.), samples were analysed using a column-switching HPLC method and detected by fluorimetry (Champmartin et al., 2007). Due to the large number of substances contained in these industrial matrices, the sample was purified on three columns using the heart-cutting technique before analysis. This technique allows rapid on-line isolation of $\mathrm{BaP}$ and its determination in parts-per-billion.

\section{Results}

BaP concentrations were very variable depending on the location inside the furnace from which deposits were sampled; whereas deposits inside the heating chambers and on the graphite elements presented low concentrations; other samples contained $\mathrm{BaP}$ at concentrations of up to $26 \mathrm{~g} / \mathrm{kg}$ (Table S2).

In furnaces using propane, these deposits looked like tar and were located in the annular space, on and around the door of the heating chambers (outside the thermally insulated casing), on the inner wall of the central tunnel, on the transfer cart, and on the tar filter (Figure 1). Tar-like residues were also found in cold areas on the gas outlet path. Slightly lower concentrations were measured in the oil of the vacuum pump $(0.11 \mathrm{~g} / \mathrm{kg})$.

In furnaces using acetylene, some deposits had the appearance of brown-orange powders. The locations of the highest concentrations of by-products were the same as in furnaces using propane, except for the central tunnel and the transfer cart, where low levels of $\mathrm{BaP}$ were found. This difference was not due to the gas used, but rather to a difference between the installations. The furnace in factory 4 had gas-tight doors between the heating chambers and the tunnel (see Discussion section). In the tunnel and on the transfer cart, not enough solid deposit was produced to allow its collection. Nevertheless, some surface samples were taken using swabbing techniques. These samples contained only low amounts of BaP. In contrast, deposits with high $\mathrm{BaP}$ concentrations - up to $9 \mathrm{~g} / \mathrm{kg}$ - were found on gas outlet pipelines. Thus, gas-tight doors confined deposits to a smaller area (doors, annular spaces, process valves and gas exhaust pipelines) than setups without gas-tight doors. 
Table S2. Overview of the BaP concentrations in the various samples collected during campaigns in factories 1 and 3 (CTLF furnace using propane) and factory 4 (CTLF furnace using acetylene). To view sampling location, see Figure 1.

\begin{tabular}{lll}
\hline Tar on the inner wall of the central tunnel (max value) & 26 \\
& & \\
\hline Tar in the annular space of the heating chamber and on & 16 & 2 \\
components inside (e.g. part of the quartz resistance) & & $*$ \\
\hline Tar on the inner wall of the central tunnel (min value) & 5 & $*$ \\
\hline Tar on the transfer cart & 5 & 4 \\
\hline Tar in the tar filter & 4 & $* *$ \\
\hline Dust inside the gas blasting nozzles & 0.21 & $* .06$ \\
\hline Oil in the vacuum pump & $4810^{-3}$ & $5310^{-6}$ \\
\hline Dust on the floor of the gas quenching chamber & & \\
\hline Dust in the casing inside the heating chamber and on the & $7810^{-6}$ & \\
components inside (e.g. graphite heating elements) & & \\
\hline$*:$ no deposit was found in this location
\end{tabular}

**: sampling and analysis not performed 


\section{Section S4: References}

Champmartin C, Simon P, Delsaut P, Dorotte M, Bianchi B. (2007) Routine determination of benzo[a]pyrene at part-per-billion in complex industrial matrices by multidimensional liquid chromatography. J. Chromatography A; 1142: 164-171. 